\title{
INFLUENCE OF SEASONAL VARIATIONS ON YIELD AND YIELD COMPONENTS OF SUNFLOWER
}

\author{
Fayyaz-ul-Hassan $^{1^{*}}$, Mumtaz Akhtar Cheema ${ }^{2}$, Ghulam Qadir ${ }^{1}$ \\ and Ch. M. Azim ${ }^{1}$ \\ ${ }^{1}$ University of Arid Agriculture, Rawalpindi, Pakistan \\ ${ }^{2}$ University of Agriculture, Faisalabad, Pakistan \\ Received: May 05, 2004 \\ Accepted: November 22, 2005 \\ SUMMARY

\begin{abstract}
Wide adaptability of sunflower and wide range of climatic conditions existing in Pakistan make it possible to have two crops of sunflower in a year, i.e., in spring and fall. Field experiments, one in spring and another in fall were conducted at the University of Arid Agriculture, Rawalpindi, Pakistan, to evaluate the influence of seasonal variations on yield and yield components of sunflower. Five sunflower hybrids were planted in a randomized complete block design in three replications. Two inner rows were harvested for measurements of yield and yield components. It was observed that head size of spring crop was larger than fall crop. Contrary to head size, 1000-seed weight of the fall crop was larger than that of the spring crop. However, final yield of the spring crop was greater than that of the fall crop. It led to the conclusion that having spring crop is the best option, while fall crop could be supplementary one, to increase the production of oilseeds.
\end{abstract}

Key words: head diameter, yield components, seasonal variation, non-conventional oilseeds

\section{INTRODUCTION}

The major sources of edible oil production in Pakistan are the conventional oilseeds crops (cottonseed, rapeseed, mustard and sesame) and non-conventional oilseed crops (sunflower and soybean). Except for cotton, the traditional oilseeds are grown on marginal lands. That is why the gap between the local production and consumption of edible oil is widening each year. Among the non-conventional oilseed crops, sunflower has the potential to narrow the existing gap between production and consumption of edible oil. Sunflowers grown in the country have the potential to yield up to $3,000 \mathrm{~kg} \mathrm{ha}^{-1}$, however, the average yield in Pakistan is 1400 $\mathrm{kg} \mathrm{ha}^{-1}$ (Govt. of Pakistan, 2003).

\footnotetext{
* Corresponding author, Fax: 92-51-9290160, e-mail: drsahi@hotmail.com
} 
Although sunflower is a temperate zone crop, it can perform well under various climatic and soil conditions. The wide adaptability of the crop and the wide range of climatic conditions of Pakistan make it possible to have two sunflower crops in one year. Amir and Khalifa (1991) concluded that sunflower could germinate and grow successfully across a wide range of climatic environments including hot tropical climates. Similarly, Khalifa et al. (2000) concluded that wide geographic, morphological and habitat-wise diversity of sunflower, extending from very hot to very cold areas, might have developed the unique characteristics of sunflower tolerance to both low and high temperature and accounted for the wide adaptation of the crop.

Experimental and farm research trials have indicated that in Pakistan sunflower can successfully be grown in two seasons (spring and fall) due to its wide range of adaptability (Rana et al., 1991). In spring season, sunflower is sown under low temperatures of January and February. It grows vegetatively under a range of low to medium temperatures of February and March before entering the reproductive stage. The reproductive stage unfolds under high temperatures of May while maturation and harvest take place under high temperature of June/July. Contrary to the spring crop, the fall crop is sown at high temperature and humidity conditions of July - August. It germinates and grows vegetatively during high to medium temperatures of August and September before entering the reproductive stage. The reproductive phase of fall crop unfolds at medium temperatures of October. The crop matures and is harvested under low temperatures of November. So, two opposite sets of environmental conditions prevail from germination to maturity of sunflower when it is grown in two seasons, i.e., in spring and fall. The overall length of sunflower life cycle is affected accordingly. Germination and vegetative stage of the spring crop take a relatively long time due to lower temperature as compared with the fall crop where these stages take place under high temperatures, taking less time and completing the life cycle in a short period of time.

Sunflowers being grown in opposite environmental conditions, all development phases are affected accordingly. The present study was contemplated to evaluate the seasonal variation effects on yield and yield components of sunflower hybrids.

\section{MATERIAL AND METHODS}

Field experiments were conducted at the University of Arid Agriculture, Rawalpindi, during spring and fall 2002 to quantify the effects of seasonal variations on yield and yield components of sunflower. The spring crop was sown on $23^{\text {rd }}$ February, the fall crop on $18^{\text {th }}$ August. Five sunflower hybrids viz. Parsun-1, Suncross-42, SMH-9706, SMH-9707 and XF-263, were sown in a randomized complete block design with three replications. There were 4 rows of $5 \mathrm{~m}$ length, $75 \mathrm{~cm}$ apart in each plot making a plot size of $5 \mathrm{~m} \times 3 \mathrm{~m}$. Plant to plant distance was maintained at $25 \mathrm{~cm}$. Uniform doses of fertilizers of $120 \mathrm{~kg} \mathrm{~N}$ and $60 \mathrm{~kg} \mathrm{P}_{2} \mathrm{O}_{5}$ per hectare were applied in the form of urea and DAP and mixed with soil during land 
preparation. Planting was done by the dibbler, placing 3-4 achenes per hill at a depth of 3-5 cm. After germination, one seedling per hill was maintained by manual thinning. Weeding and hilling were done manually when needed.

Cumulative growing degree-days were calculated by the equation of Dwyer and Stewart (1986).

$$
\begin{gathered}
\text { CGDD }=\sum_{\mathrm{t}_{1}\left[\left(\mathrm{~T}_{\text {Max }}+\mathrm{T}_{\text {Min }}\right) / 2-10\right]}^{\mathrm{t}_{2}} \\
\text { where }\left[\left(\mathrm{T}_{\text {Max }}+\mathrm{T}_{\text {Min }}\right) / 2-10\right] \geq 0
\end{gathered}
$$

$\mathrm{T}_{\text {Max }}+\mathrm{T}_{\text {Min }}$ are daily maximum and minimum air temperatures in degrees centigrade and $t_{1}$ and $t_{2}$ are time intervals. Base temperature for sunflower was $8^{\circ} \mathrm{C}$ (Sadras and Hali, 1988).

Two inner rows of the spring and fall crops were harvested on $16^{\text {th }}$ June and $11^{\text {th }}$ November 2002, respectively. Ten heads were randomly selected in each variant for the measurement of head diameter. Head diameter was measured with measuring tape (Sublime Sports Ltd., Sialkot, Pakistan) and averages were calculated. All heads were threshed manually. Three lots of 1000 seeds were separately weighed with an analytical balance (Technic Instruments Ltd., UK) and the average was calculated. All seeds from two inner rows were then weighed separately and yield was calculated on per hectare basis. The collected data were subjected to statistical analysis appropriate for randomized complete block design using microcomputer MSTAT, separately for both seasons (Freed and Eisensmith, 1986). Duncan's multiple range test (Duncan, 1955) was used for separation of treatment means.

\section{RESULTS AND DISCUSSION}

The hybrids produced heads of different sizes in spring. The hybrid SMH-9707 produced the largest head $(17.63 \mathrm{~cm})$, while XF-263 produced the smallest head $(13.43 \mathrm{~cm})$ (Table 1$)$. The hybrid SMH-9707 was significantly different $(P=0.5)$ from Parsun-1 and XF-263 while it was at par with the hybrids SMH-9706 and Suncross- 42 .

Table 1: Influence of seasonal variation on yield and yield components of sunflower

\begin{tabular}{lcccccc}
\hline \multirow{2}{*}{ Hybrid } & \multicolumn{9}{c}{ Parameter } \\
\cline { 2 - 7 } & \multicolumn{2}{c}{ Sead diameter $(\mathrm{cm})$} & \multicolumn{2}{c}{ TSW $(\mathrm{g})$} & \multicolumn{2}{c}{ Seed yield $\left(\mathrm{kg} \mathrm{ha}^{-1}\right)$} \\
\cline { 2 - 7 } & $15.83 \mathrm{~b}$ & $13.42 \mathrm{a}$ & $35.58 \mathrm{a}$ & $38.53 \mathrm{a}$ & $1757 \mathrm{~b}$ & Season \\
\cline { 2 - 7 } & $16.10 \mathrm{ab}$ & $14.64 \mathrm{a}$ & $35.73 \mathrm{a}$ & $42.33 \mathrm{a}$ & $2122 \mathrm{a}$ & $1631 \mathrm{~b}$ \\
SARSUN -1 & $17.63 \mathrm{a}$ & $15.26 \mathrm{a}$ & $34.63 \mathrm{a}$ & $40.85 \mathrm{a}$ & $1738 \mathrm{~b}$ & $1353 \mathrm{c}$ \\
SMH-9707 & $16.13 \mathrm{ab}$ & $15.58 \mathrm{a}$ & $36.43 \mathrm{a}$ & $45.08 \mathrm{a}$ & $2175 \mathrm{a}$ & $1827 \mathrm{a}$ \\
SUNCROSS-42 & $13.43 \mathrm{c}$ & $10.37 \mathrm{~b}$ & $21.27 \mathrm{~b}$ & $27.81 \mathrm{~b}$ & $940 \mathrm{c}$ & $768 \mathrm{~d}$ \\
XF-263 & & Fall & Spring & Fall & Spring & Fall \\
\hline
\end{tabular}

Treatment means followed by the same letter are not significantly different at $P=0.05$ 
Head diameter of all hybrids decreased in fall as compared with the spring crop. However, variations in head diameter of the fall crop were narrow. The largest head $(15.58 \mathrm{~cm})$ was produced by Suncross-42, while XF-263 again produced the smallest one $(10.37 \mathrm{~cm})$. All hybrids were significantly different from XF-263 and mutually similar regarding this parameter.

Reduction in head size in the fall crop varied from 3 to $22 \%$. The minimum reduction (3\%) was observed in Suncross-42, the maximum (22\%) in XF-263. In the hybrids SMH-9607, SMH-9606 and Parsun-1, the recorded reductions were $9 \%, 13 \%$ and $15 \%$, respectively.

The reduction of head diameter in the hybrids may be the result of a combined action of LAI, plant structure (plant height \& dry matter) and environmental factors. The superior plant structure (leaf area index, plant height and dry matter) of the spring crop might have encouraged the development of larger heads. Ujjinaiah et al. (1987) found smaller heads in a fall crop than in a spring crop, while Ahmad (2001) reported significant relationships of plant height and head diameter in spring $\left(r^{2}=0.62\right)$ and fall crops $\left(r^{2}=0.90\right)$. The longer sunflower life cycle of the spring crop, with more cumulative degree-days, might also have contributed to the development of larger heads. Accordingly, the fall crop developed smaller heads because it spent a shorter period of time in the field and accumulated less degreedays.

Thousand-seed weight (TSW) varied in the spring crop. The hybrid Suncross42 produced the maximum TSW (36.43 g), which was significantly $(P=0.05)$ different from that of XF-263 (21.27 g) but which was at par with those of the other hybrids (Table 1 ).

Thousand-seed weight of the fall crop increased as compared with that of the spring crop. This was contrary to all other parameters which showed a decline. The hybrid Suncross-42 produced the maximum 1000-seed weight ( $45.08 \mathrm{~g}$ ), which was significantly different from XF-263 (27.81 g) but at par with those of the other hybrids.

The increases in TSW of the fall crop ranged from 8 to $31 \%$. The minimum increase (8\%) was recorded in Parsun-1, the maximum (31\%) in XF-263. The increases of TSW in SMH-9606, SMH-9607 and Suncross-42 were 17.9, 18.19 and $23.16 \%$, respectively.

The relatively large heads of the spring crop encouraged the setting of a larger number of seeds per head. These extra seeds required a greater amount of assimilates which was not possible for plant to supply, thus creating a competition for assimilates. The competition for assimilates and the rapid rise in cumulative degree-days (Figure 4) at the time of seed development and maturation might have left many seeds malnourished resulting in lower 1000-seed weight from that of the spring crop. Small heads of the fall crop would have allowed a smaller number of seeds to complete development in the limited space. Less seeds would have an adequate amount of assimilates for proper development and maturation. Teklewold et 
al. (2000) concluded that increase in head size simultaneously increased the husk percentage and incidence of empty seed, reducing the TSW. The significant linear relationship between head diameter and 1000-seed weight (Figure 1) supports the view that 1000-seed weight is directly dependent on head size.
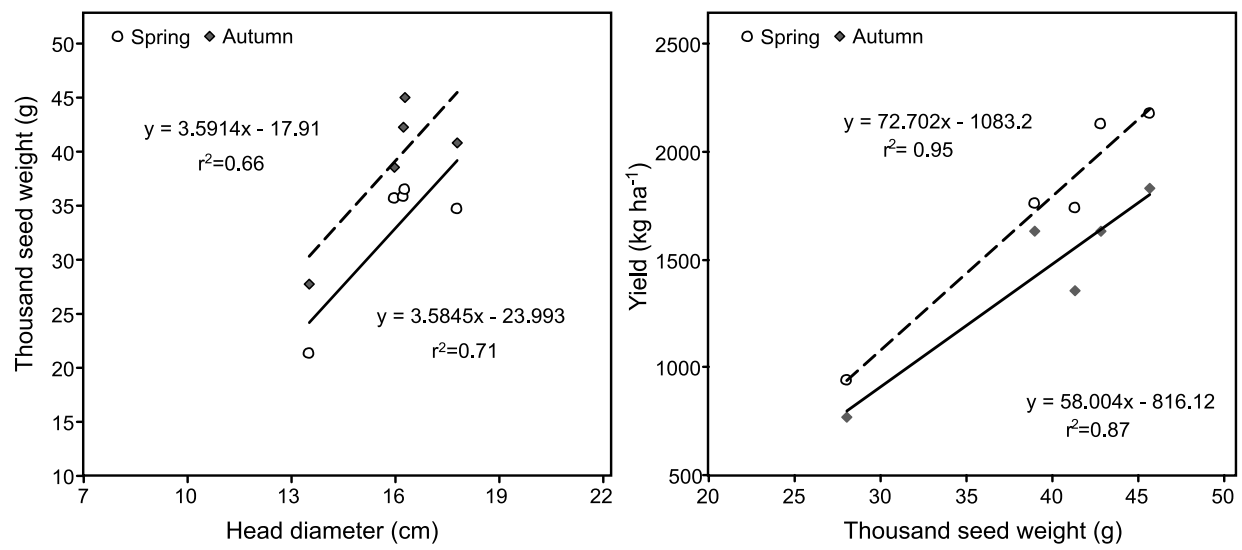

Figure 1: Relationship between head diame- Figure 2: Relationship between 1000-seed ter and 1000-seed weight weight and seed yield

All hybrids sown in spring showed variation in seed yield. The hybrid Suncross- 42 produced the highest seed yield $(2175 \mathrm{~kg} / \mathrm{ha})$, which was significantly $(P=$ 0.5) different from the yields of all other hybrids except that of SMH-9706. The hybrid XF-263 produced the lowest yield (940.30 kg/ha) (Table 1).

All hybrids had a lower seed yield in the fall as compared with the spring. The hybrid Suncross-42 produced the maximum yield (1827 kg/ha), XF-263 the minimum $(740 \mathrm{~kg} / \mathrm{ha})$. The hybrid Suncross-42 was found to be significantly different from all other hybrids, in contrast to the spring, but it was at par with SMH-9706.

The overall reduction in yield ranged between 7 and 23\%. The minimum reduction (7\%) was recorded in Parsun-1, the maximum (23\%) in SMH-9607. The reductions in SMH-9606, XF-263 and Suncross-42 were 22, 18 and 16\%, respectively.

Seed yield is a combined function of different components. The comparison of both parameters, i.e., head size and 1000-seed weight revealed that final yield dependence is inclined more towards the latter parameter. Chaudhary and Anand (1993) observed a high positive direct influence of head diameter on seed yield. However, Patil et al. (1996) reported a low positive direct effect of head diameter on seed yield. The significant linear relationship between 1000-seed weight and final yield (Figure 2) contradicts the earlier hypothesis. The non-significant relationship between head diameter and final seed yield (Figure 3) supports the earlier findings of Patil et al. (1996). The higher yield obtained from the spring crop confirms the earlier results of Habibullah et al. (1983) who reported that spring crop has the overall advantage of better plant structure and better environmental conditions during crop growth period and maturity than fall crop. Better environmental conditions for spring crop are the slow and gradual rise in cumulative growing degree- 
days. Degree days accumulated during sunflower crop life cycle are presented in Figure 4 .
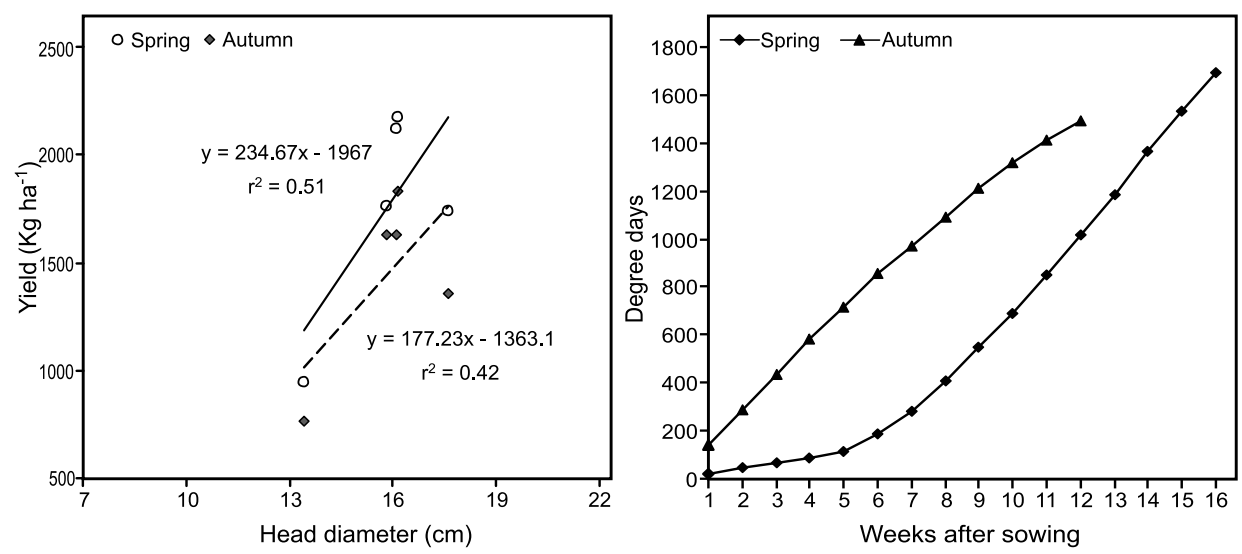

Figure 3: Relationship between head diame- Figure 4: Degree-days accumulated during ter and seed yield crop life cycle

It can be concluded from the above findings that spring crop is superior over fall crop in terms of yield. However, fall crop could be fitted well in the present cropping system of Pakistan, to overcome the deficiency of edible oils.

\section{REFERENCES}

Ahmad, R.A., 2001. Seasonal variation in growth and development of sunflower hybrids. M.Sc. Hons., Thesis, University of Arid Agriculture, Rawalpindi, Pakistan.

Amir, H.A. and Khalifa, F.M., 1991. Performance and yield of sunflower cultivars under rainfed and irrigated conditions in Sudan. Jour. Agric. Sci. Cambridge, 116: 245-261.

Dwyer, L.M. and Stewart, D.W., 1986. Leaf area development in field grown maize. Agron. J. 78: 334-343.

Freed, R.D. and Eisensmith, S.P., 1986. MSTAT Microcomputer Statistical Program. Michigan State University of Agriculture and Applied Science, Michigan, Lansing, USA.

Chaudhary, S.K. and Anand, I.J., 1993. Correlation and path-coefficient analysis in $\mathrm{F}_{1}$ and $\mathrm{F}_{2}$ generations in sunflower (Helianthus annuus L.). Int. J. Trop. Agric. 11: 204-208.

Duncan, D.B., 1995. Multiple range and multiple F test. Biometrics 11: 1-42.

Govt. of Pakistan, 2003. Economic Survey, Finance Division, Economic Advisor's Wing, Islamabad, Pakistan, P-16.

Habibullah, B.T., Mamickam, S., Multruuel, P. and Chamy, R., 1983. Effects of planting date on production of sunflower. Madras Agric. J. 70(6): 382-384.

Khalifa, F.M., Schnetter, A.A. and El-tayeb, E.I., 2000. Temperature-germination response of sunflower (Helianthus annuus L.) genotypes. Helia 23(33): 97-104.

Patil, B.R., Rudraradhya, M., Vijayakumar, M.C.H., Basappa, H. and Kulkarni, R.S., 1996. Correlation and path analysis in sunflower. J. Oilseed Res. 13(2): 157-161.

Rana, M.A., Khan, M.A. Yousaf M. and Mirza, M.S., 1991. Evaluation of 26 sunflower hybrids at Islamabad. Helia 14: 19-28.

Sadras, V.O. and Hali, A.J., 1988. Quantification of temperature, photoperiod and population effect on plant leaf area in sunflower crop. Field Crop Res. 18: 185-196.

Teklewold, A., Jayaramaiah, H. and Jagadeesh, B.N., 2000. Correlations and path analysis of physio-morphological characteristics of sunflower (Helianthus annuus L.) as related to breeding method. Helia 23(32): 105-114.

Ujjinaiah, U.S., Seenappa, K. and Makadevappa, M., 1987. Effect of season on seed quality of sunflower. Mysore J. Agric. Sci. 23(3): 311-314. 


\title{
INFLUENCIA DE LAS VARIACIONES ESTACIONALES EN EL RENDIMIENTO Y COMPONENTES DE RENDIMIENTO EN GIRASOL
}

\author{
RESUMEN
}

La amplia adaptabilidad de girasol y gran rango de condiciones climatológicas que existen en Pakistán, posibilitan la obtención de dos cosechas de girasol anuales, una en primavera, y otra en otoño. Los experimentos de campo, en primavera y en otoño, fueron realizados en la Universidad de Agronomía, Rawalpindi, Pakistán, en las condiciones de sequía, para evaluar la influencia de las variaciones estacionales en el rendimiento y los componentes de rendimiento en girasol. Cinco girasoles híbridos fueron sembrados en el sistema de bloques al azar, en tres repeticiones. Dos filas interiores fueron utilizadas para la medición del rendimiento y los componentes de rendimiento. Fue observado que las cabezas eran mayores en la plantación primaveral que en la plantación otoñal. Frente al tamaño de la cabeza, el peso de 1000 granos, era mayor en la plantación otoñal. No obstante, el rendimiento definitivo de la plantación primaveral era mayor del otoñal. Eso indica la conclusión que el cultivo primaveral es la óptima variante, y el cultivo en el otoño se puede considerar como complementario, para incrementar la producción de aceite total.

\section{EFFET DES VARIATIONS SAISONNIÈRES SUR LE RENDEMENT ET SUR LES COMPOSANTS DU RENDEMENT DU TOURNESOL}

\section{RÉSUMÉ}

La grande adaptabilité du tournesol et la vaste gamme de conditions climatiques existant au Pakistan permettent l'obtention de deux récoltes de tournesol par année, l'une au printemps, l'autre à l'automne. Des expériences sur le terrain, l'une au printemps et l'autre à l'automne ont été effectuées à l'Université d'agronomie dans des conditions de sécheresse, à Rawalpindi, au Pakistan pour évaluer l'effet des variations saisonnières sur le rendement et les composants de rendement du tournesol. Cinq hybrides de tournesol ont été plantés en trois fois selon le système de blocs randomisés. Les deux allées centrales ont servi à mesurer le rendement et les composants du rendement. On a constaté que les têtes étaient plus grandes au printemps qu'à l'automne. À l'inverse, le poids de 1000 graines était plus important à l'automne qu'au printemps. Cependant, le rendement final de la culture de printemps était plus important que celui de la culture automnale. Cela nous permet de conclure que la culture de printemps est plus profitable que celle de l'automne et que la culture d'automne peut être considérée comme une récolte supplémentaire faite dans le but d'augmenter la production d'huile. 
